\title{
Estradiol Reverses a Calcium-Related Biomarker of Brain Aging in Female Rats
}

\author{
Lawrence D. Brewer, ${ }^{*}$ Amy L. S. Dowling, ${ }^{\star}$ Meredith A. Curran-Rauhut, Philip W. Landfield, Nada M. Porter, and \\ Eric M. Blalock \\ Department of Molecular and Biomedical Pharmacology, University of Kentucky, Lexington, Kentucky 40536
}

An increase in L-type voltage-gated calcium channel (LTCC) current is a prominent biomarker of brain aging and is believed to contribute to cognitive decline and vulnerability to neuropathologies. Studies examining age-related changes in LTCCs have focused primarily on males, although estrogen (17 $\beta$-estradiol, E2) affects calcium-dependent activities associated with cognition. Therefore, to better understand brain aging in females, the effects of chronic E2 replacement on LTCC current activity in hippocampal neurons of young and aged ovariectomized rats were determined. The zipper slice preparation was used to expose cornu ammonis 1 (CA1) pyramidal neurons for recording LTCC currents using the cell-attached patch-clamp technique. We found that an age-related increase in LTCC current in neurons from control animals was prevented by $\mathrm{E} 2$ treatment. In addition, in situ hybridization revealed that within stratum pyramidale of the $\mathrm{CA} 1$ area, $\mathrm{mRNA}$ expression of the $\mathrm{Ca}_{\mathrm{v}} 1.2 \mathrm{LTCC}$ subunit, but not the $\mathrm{Ca}_{\mathrm{v}} 1.3$ subunit, was decreased in aged $\mathrm{E} 2$-treated rats. Thus, the reported benefits of E2 on cognition and neuronal health may be attributed, at least in part, to its age-related decrease in LTCC current.

\section{Introduction}

Changes in calcium $\left(\mathrm{Ca}^{2+}\right)$ homeostasis are prominent components of brain aging and contribute to impaired cognition and increased vulnerability to excitotoxicity and neurodegenerative diseases (Landfield, 1987; Thibault et al., 1998; Coon et al., 1999; LaFerla, 2002; Burke and Barnes, 2006; Disterhoft and Oh, 2006; Murchison and Griffith, 2007; Raza et al., 2007). Well established electrophysiological biomarkers of hippocampal aging include increases in both L-type voltage-gated calcium channel (LTCC) currents and the $\mathrm{Ca}^{2+}$-dependent slow afterhyperpolarization (AHP) (Thibault and Landfield, 1996; Power et al., 2002). These age-related changes in hippocampal cornu ammonis 1 (CA1) pyramidal neurons contribute to impaired synaptic plasticity and likely underlie a decrease in cognitive acuity (Deyo et al., 1989; Shankar et al., 1998; Thibault et al., 2001; Veng et al., 2003).

Most studies examining age-related changes in $\mathrm{Ca}^{2+}$ regulation have been conducted in male animals, although sexual dimorphism is evident in many brain regions not directly associated with reproduction, including the hippocampus (Juraska, 1991; McEwen, 1999; Cahill, 2006). The steroid hormone estrogen (17 $\beta$-estradiol, E2) plays an important role in neuroprotection and synaptic plasticity, both of which are $\mathrm{Ca}^{2+}$-dependent

\footnotetext{
Received 0ct. 31, 2008; revised March 1, 2009; accepted April 3, 2009.

This research was supported by National Institutes of Health Grants R01AG020251 (to N.M.P.) and P01AG010836 (to P.W.L.) and Training Grant T32AG000242 (to Dr. D. M. Gash, Department of Anatomy and Neurobiology, University of Kentucky, Lexington, KY). We are grateful to Dr. Thomas Foster for valuable discussions regarding anima surgery and dietary phytoestrogens. We also thank Dr. Olivier Thibault for comments on an earlier version of this manuscript and Michael T. Bridges for assistance with in situ hybridization.

*L.D.B. and A.L.S.D. contributed equally to this work.

Correspondence should be addressed to either Nada M. Porter or Eric M. Blalock, Department of Molecular and Biomedical Pharmacology, 800 Rose Street UKMC/MS-315, University of Kentucky, Lexington, KY 40536, E-mail: nadap@uky.edu or embla!@uky.edu.

DOI:10.1523/JNEUROSCI.5253-08.2009

Copyright $\odot 2009$ Society for Neuroscience $\quad 0270-6474 / 09 / 296058-10 \$ 15.00 / 0$
}

processes (Wong and Moss, 1992; Dubal et al., 1998; Woolley, 1998; Foy et al., 1999; Hurn and Macrae, 2000; Yang et al., 2000; Bi et al., 2001; Behl, 2002; Nilsen and Brinton, 2003). In female rodents, high levels of E2 during the proestrus phase of the estrus cycle enhance hippocampal excitability and long-term potentiation (LTP) (Teyler et al., 1980; Warren et al., 1995; Good et al., 1999; Bi et al., 2001). Furthermore, this occurs simultaneously with an increase in dendritic spines and synapses (Woolley et al., 1990; Woolley and McEwen, 1992). These results suggest that the decline in E2 associated with aging and reproductive senescence may have significant effects on plasticity in the aging female brain (Yun et al., 2007; Foy et al., 2008).

$\mathrm{Ca}^{2+}$-related biomarkers of aging may also be targets of E2 action. For example, E2 reduces the AHP and facilitates LTCCmediated signaling pathways involved in neuroprotection (Kelly et al., 1980; Kumar and Foster, 2002; Carrer et al., 2003; Wu et al., 2005; Kelly and Rønnekleiv, 2008). Furthermore, LTCC currents are increased in cardiac myocytes from estrogen receptor knockout (ERKO) mice (Johnson et al., 1997). Whether LTCCs are altered with aging in females in a manner similar to males and whether E2 affects LTCCs in vivo is unknown. Because LTCCs have a broad role in neuronal function and are altered with aging, we examined the effects of E2 on these channels.

Here, the effects of age and E2 replacement on LTCC activity and expression in hippocampal CA1 pyramidal neurons were studied in ovariectomized (OVX) rats. CA1 neurons are noted for their dynamic structure and essential role in synaptic plasticity (Spruston, 2008), both of which are affected by E2 (Gould et al., 1990; Desmond and Levy, 1997; Hao et al., 2003). To specifically investigate LTCCs in CA1 neurons, we used the hippocampal zipper slice developed by Gray and colleagues (Gray and Johnston, 1987; Gray et al., 1990) which allows unobstructed access to adult CA1 cell bodies for patch-clamp recording 
(Thibault and Landfield, 1996; Norris et al., 2008). Additionally, we used in situ hybridization (ISH) to study the effects of age and $\mathrm{E} 2$ on mRNA expression of the $\mathrm{Ca}_{\mathrm{v}} 1.2$ and $\mathrm{Ca}_{\mathrm{v}} 1.3$ LTCC poreforming subunits in the $\mathrm{CA} 1$ region. We found that $\mathrm{E} 2$ treatment reversed an age-related increase in LTCC current and decreased mRNA expression of the $\mathrm{Ca}_{\mathrm{v}} 1.2$ subunit in aged animals. These results may have clinical implications, given that some aspects of hippocampal brain aging in females can be reversed by in vivo treatment with E2.

\section{Materials and Methods}

Ovariectomy and implantation of E2 Silastic capsules

Young adult (5-6 months old) and aged (21-22 months old) female Fischer 344 (F344) rats were obtained from Harlan and housed in our animal facilities in accordance with National Institutes of Health (NIH) Guidelines and protocols approved by the Institutional Animal Care and Use Committee of the University of Kentucky. Rats were maintained under controlled temperature and photoperiod conditions ( $12 \mathrm{~h}$ light/ dark) with food and water available ad libitum. To reduce the contribution of dietary phytoestrogens derived from standard rodent chows (Degen et al., 2002), rats were placed on a casein-based diet (soy- and alfalfafree diet; Purina 5K96; Purina Mills) on arrival and acclimated to this diet for 2 weeks before any manipulations. No changes in weight or food intake were observed during this period.

Rats were anesthetized using isoflurane anesthesia, and bilateral OVX was performed. OVX reduces E2 levels by $\sim 75-85 \%$ in young adult female rats (Yang et al., 2000; Dubal and Wise, 2001). We have found that E2 levels in aged intact and aged OVX F344 rats are not significantly different and are similar to levels in young OVX rats (M. A. CurranRauhut and N. M. Porter, unpublished observations). All rats were immediately implanted with two subcutaneous Silastic capsules (Dow Corning; inner diameter, $1.58 \mathrm{~mm}$; outer diameter, $3.18 \mathrm{~mm}$; length, 20 $\mathrm{mm}$ for young, $30 \mathrm{~mm}$ for aged) containing either vehicle (sesame oil) or E2 $(200 \mu \mathrm{g} / \mathrm{ml}$ dissolved in sesame oil; Sigma-Aldrich). Capsules were placed dorsally on each side of the thoracic vertebrae and reliably delivered E2 for 3 weeks before being replaced under isoflurane anesthesia in animals receiving longer treatments. Animals were treated for 2-6 weeks before electrophysiological recording. Treatment durations differed because electrophysiological analyses could only be performed on one animal per day.

\section{Electrophysiology}

Zipper slice preparation. Methods for preparing partially dissociated hippocampal "zipper" slices were originally developed by Gray et al. (1990) for tissue isolated from guinea pigs and modified for use in rats, as described previously by our laboratory (Thibault and Landfield, 1996; Blalock et al., 2001; L. D. Brewer et al., 2006). The advantage of this preparation is that it provides isolated cell bodies suitable for patch clamping.

Vehicle- or E2-treated animals ( $n=4$ animals/group) were deeply anesthetized with $\mathrm{CO}_{2}$ and then decapitated. Brains were quickly removed and briefly placed (1-2 min) into ice-cold, oxygenated (95\% $\mathrm{O}_{2} / 5 \% \mathrm{CO}_{2}$ ) artificial CSF (ACSF; low $\mathrm{Ca}^{2+}$ concentration) containing the following (in mM): $1.25 \mathrm{KH}_{2} \mathrm{PO}_{4}, 114 \mathrm{NaCl}, 2.5 \mathrm{KCl}, 2 \mathrm{MgCl}_{2}, 30$ $\mathrm{NaHCO}_{3}, 10$ glucose, and $0.1 \mathrm{CaCl}_{2}$. Hippocampi were isolated and cut into $350-\mu \mathrm{m}$-thick transverse slices with a McIlwain tissue chopper (Brinkmann) and placed into oxygenated, $32^{\circ} \mathrm{C}$ ACSF containing $2 \mathrm{~mm}$ $\mathrm{CaCl}_{2}\left(\mathrm{Ca}^{2+}-\mathrm{ACSF}\right)$. Slices were incubated for $30 \mathrm{~min}$ in $3 \mathrm{ml}$ of $32^{\circ} \mathrm{C}$ $\mathrm{Ca}^{2+}-$ ACSF containing $2.1 \mathrm{mg}$ pronase (Calbiochem) and continuously oxygenated throughout remaining incubations. This solution was then replaced with $3 \mathrm{ml}$ of $32^{\circ} \mathrm{C} \mathrm{Ca}^{2+}-\mathrm{ACSF}$ containing $1.7 \mathrm{mg}$ thermolysin (protease type X; Sigma-Aldrich). After $20 \mathrm{~min}$, half of the thermolysin $\mathrm{Ca}^{2+}-\mathrm{ACSF}$ solution was removed and replaced with $\mathrm{Ca}^{2+}-\mathrm{ACSF}$.

After $30 \mathrm{~min}$ in $\mathrm{Ca}^{2+}$-ACSF, slices were ready for mild dissociation. An individual slice was nicked at the edge of the CA1 layer (Fig. $1 A$ ) and placed into a $2 \mathrm{ml}$ autoanalyzer cup (Fisher Scientific) containing oxygenated EGTA-ACSF ( $2 \mathrm{~mm}$ EGTA substituted for $2 \mathrm{~mm} \mathrm{CaCl}_{2}$ ). The slice was gently shaken until separation or "unzipping" of the CA1 layer was visible (Fig. $1 B, C$ ), at which time the slice was transferred to a

\section{A. Intact slice bathed in protease solution.}

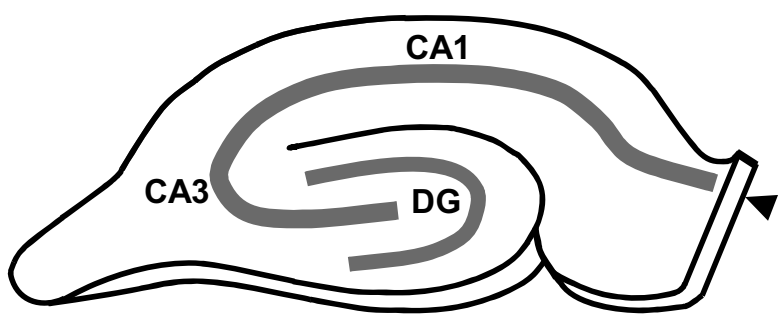

B. Zipper slice: Unzipped CA1 layer with exposed neurons.

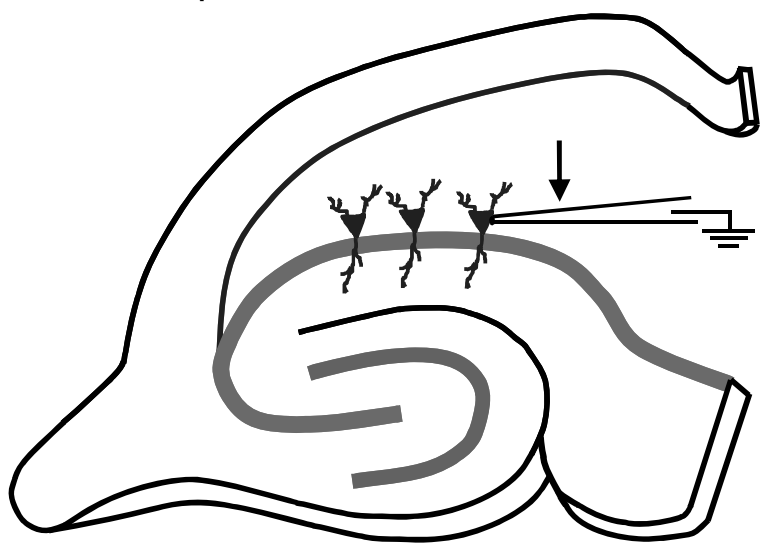

\section{Zipper slice with a patch-electrode attached to a neuron.}

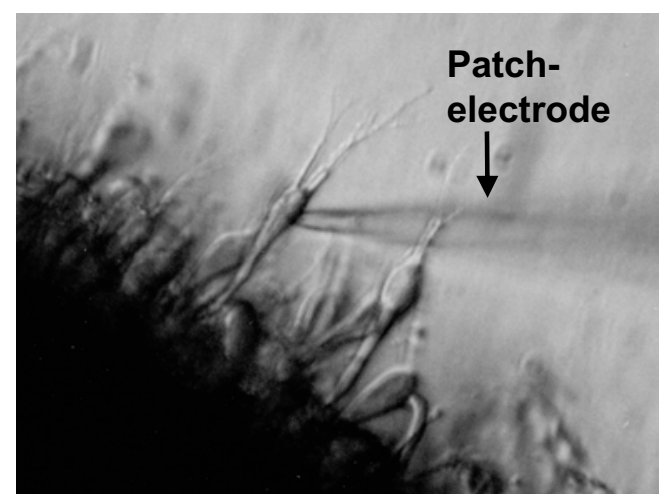

Figure 1. Hippocampal zipper slice preparation used to expose CA1 pyramidal neurons for multichannel recording of LTCC activity with a traditional cell-attached patch pipette. $A$, Schematic of an intact hippocampal slice with the CA1, CA3, and DG regions labeled. Arrowhead indicates location where a nick is made along the CA1 region. $B$, Schematic of the partially dissociated hippocampal slice showing the unzipped (A1 region (zipper slice) with exposed pyramidal cell bodies and a patch electrode (arrow). A combination of proteases followed by mild shaking unzips the CA1 layer. C, Photomicrograph of a zipper slice preparation with a patch electrode (arrow) sealed to the membrane of a CA1 pyramidal neuron. The cell-attached patch electrode was used to record multichannel LTCC activity from these neurons.

perfusion-style recording chamber (Warner Instruments) containing external recording solution (see below).

Cell-attached patch-clamp recording of L-type $\mathrm{Ca}^{2+}$ channels. Multichannel cell-attached patch-clamp recordings of LTCCs from CA1 pyramidal neurons were performed as described previously (Thibault and Landfield, 1996; Blalock et al., 2001; L. D. Brewer et al., 2006). A "zeroing" solution was used for the external recording medium (Fox et al., 
1987) and contained (in $\mathrm{mm}$ ) $140 \mathrm{~K}$ gluconate, $3 \mathrm{MgCl}_{2}, 10$ glucose, 10 EGTA, and 10 HEPES; pH adjusted to 7.35 with $\mathrm{KOH}$ and osmolarity adjusted to $300 \mathrm{mOsm}$ with distilled water. The pipette solution contained (in mM) $20 \mathrm{BaCl}_{2}, 90$ choline $\mathrm{Cl}, 10$ TEA, and 10 HEPES; pH adjusted to 7.35 with TEA-OH and osmolarity adjusted to $290 \mathrm{mOsm}$ with sucrose. The pipette also contained the LTCC dihydropyridine (DHP) agonist ( \pm )BayK8644 $(0.5 \mu \mathrm{M})$, which greatly increases the mean open time and open probability of the channel, resulting in patch currents dominated by this channel type (Thibault and Landfield, 1996).

Pyramidally shaped neurons in the CA1 field were identified for recording, and neurons appearing swollen or flattened were avoided. Cells were approached carefully with the recording pipette, as cell bodies were floating unsupported in the medium; a high-resistance seal was formed during contact, and recording in the cell-attached mode was achieved using standard protocols (Hamill et al., 1981). The average electrode resistance was $3.8 \mathrm{M} \Omega( \pm 0.09)$, and there was no significant difference between groups (one-way ANOVA). The holding current and seal resistance averaged $4.8 \pm 0.5 \mathrm{pA}$ and $22.7 \pm 1.8 \mathrm{G} \Omega$, respectively, and there was no significant difference between groups (two-way ANOVA). LTCC current was evoked from a holding potential of $-70 \mathrm{mV}$ to $0 \mathrm{mV}$ for 150 $\mathrm{ms}$. Leak currents were obtained by equivalent voltage steps in the opposite direction. Fifteen consecutive sweeps from each patch were used to construct an ensemble average current from leak-subtracted currents. The total area within the ensemble average was integrated and divided by stimulus duration to obtain an average patch current. Current-voltage $(I-V)$ relationships were determined by holding each patch at $-70 \mathrm{mV}$ and stepping in progressively greater $+10 \mathrm{mV}$ increments to $+40 \mathrm{mV}$. Half-maximal activation voltages were derived by fitting data from the $I-V$ curve to the Boltzmann equation, as described by Brewer et al. (2007) using GraphPad Prism software (GraphPad Software).

\section{In situ hybridization}

Tissue preparation. A separate group of animals of the same age and treatment groups was used for ISH studies ( $n=4-5 /$ group). After a 6 week treatment period, animals were killed by decapitation, and trunk blood was collected for measurement of plasma E2. Brains were rapidly removed and stored at $-80^{\circ} \mathrm{C}$ until they were sectioned for ISH. Coronal sections $(12 \mu \mathrm{m})$ were obtained through the hippocampal region (bregma $-3.30 \mathrm{~mm}$ to $-4.16 \mathrm{~mm}$ ) (Paxinos and Watson, 1998). Sections were thaw-mounted onto gelatin-coated microscope slides and stored at $-80^{\circ} \mathrm{C}$ until hybridization. Slides were prehybridized as described previously (Scott et al., 1998).

Probe preparation and hybridization. A 556 bp fragment of $\mathrm{Ca}_{\mathrm{v}} 1.2$ cDNA (6745-7300, accession no. M59786) and a 511 bp fragment of $\mathrm{Ca}_{\mathrm{v}} 1.3$ cDNA (6047-6557, accession no. M57682) were cloned by standard PCR methods using specific primers for each transcript (Integrated DNA Technologies). Briefly, hippocampal RNA was isolated using Trizol (Invitrogen). The RNA was then reverse transcribed according to manufacturer's instructions using random hexamers (Superscript II; Invitrogen), generating a hippocampal cDNA library. The cDNA fragment specific for $\mathrm{Ca}_{\mathrm{v}} 1.2$ was amplified using forward (5' -CCTAATGGGTTCGTTTCAGAAG- $3^{\prime}$ ) and reverse (5'-ATCAAAACCTAGAAAACCGCAA$\left.3^{\prime}\right)$ primers; the cDNA fragment specific for $\mathrm{Ca}_{\mathrm{v}} 1.3$ was amplified using forward (5'-CTGATTGGAACTGAGCAGACAG-3') and reverse (5'ATACGTCCAAGGAGCCTTTACA- $\left.3^{\prime}\right)$ primers. The cDNA fragments were amplified using $1 \mu \mathrm{M}$ of each primer, $0.2 \mathrm{~mm}$ dATP, dCTP, dGTP, and dTTP, $1.3 \mathrm{~mm} \mathrm{MgCl}_{2}$, and $1.25 \mathrm{U}$ AmpliTaq DNA polymerase (Applied Biosystems). PCR products were purified using QIAquick spin columns according to the manufacturer's instructions (Qiagen). The $556 \mathrm{bp}$ $\mathrm{Ca}_{\mathrm{v}} 1.2$ fragment and the $511 \mathrm{bp} \mathrm{Ca}_{\mathrm{v}} 1.3$ fragment were then ligated into pCRII (Invitrogen) and sequenced by ACGT, Inc.

The plasmids containing cloned regions of $\mathrm{Ca}_{\mathrm{v}} 1.2$ and $\mathrm{Ca}_{\mathrm{v}} 1.3 \mathrm{cDNA}$ were used to prepare radiolabeled cRNA probes specific for $\mathrm{Ca}_{\mathrm{v}} 1.2$ and $\mathrm{Ca}_{\mathrm{v}} 1.3$. The plasmids were linearized with either BamHI or EcoRV to generate antisense and sense cRNA transcripts, respectively. Transcription reactions were performed in the presence of ${ }^{33} \mathrm{P}-\alpha \mathrm{UTP}$ (PerkinElmer) as described previously (Scott et al., 1998), except that the reactions included $90 \mathrm{pmol}^{33} \mathrm{P}-\alpha \mathrm{UTP}$ in a total concentration of $12 \mu \mathrm{M}$ UTP. ISH using $\mathrm{Ca}_{\mathrm{v}} 1.2$ and $\mathrm{Ca}_{\mathrm{v}} 1.3$ probes was performed as described previ- ously (Dowling et al., 2000), except that the hybridization buffer contained 250,000 cpm per section.

Autoradiography and signal quantitation. After ISH, all slides were arranged in x-ray cassettes and apposed to BioMax film (Eastman Kodak) for 2 weeks. ${ }^{14} \mathrm{C}$-labeled standards (American Radiolabeled Chemicals) were simultaneously apposed to the film to verify that the film was not overexposed. The hybridization signal was analyzed using a ScanMaker i900 (Microtek) and the public domain ImageJ program (W. Rasband, $\mathrm{NIH}$ ). The relative abundance of $\mathrm{Ca}_{\mathrm{v}} 1.2$ and $\mathrm{Ca}_{\mathrm{v}} 1.3$ mRNAs was measured over the CA1 hippocampal subfields. Data were normalized by subtracting nontissue background signal from the signal measured in the $\mathrm{CA} 1$ area. The resulting values were averaged over four sections for each brain, with four to five animals per treatment group.

\section{Bioassay of E2 effects}

Radioimmunoassay of E2. Plasma E2 levels were measured in a subset of animals to ensure effectiveness of OVX and E2 implants. After killing, trunk blood was collected into heparinized Vacutainer tubes (BD Biosciences), immediately placed on ice, and centrifuged at $1000 \mathrm{~g}$ for $10 \mathrm{~min}$ at $4^{\circ} \mathrm{C}$. Plasma was isolated, aliquoted, and stored at $-20^{\circ} \mathrm{C}$. E2 levels were determined by radioimmunoassay (RIA) using an Ultra-Sensitive Estradiol RIA kit (DSL-4800; Diagnostic Systems Laboratories) according to the manufacturer's instructions. Each sample was analyzed in triplicate. This assay was performed at $32.1 \%$ binding with detection limits of $5-250 \mathrm{pg} / \mathrm{ml}$ and a theoretical sensitivity of $2.2 \mathrm{pg} / \mathrm{ml}$. The intraassay coefficient of variation $(\mathrm{CV})$ was $10.9 \%$, and the interassay $\mathrm{CV}$ was $16.5 \%$. The average circulating E2 levels ranged from 5.96 to 13.57 $\mathrm{pg} / \mathrm{ml}$ and were within the detection limits of the RIA kit (see Results).

Measurement of uterine weight. Uterine weight was measured in vehicle-treated and E2-treated OVX animals to determine the efficacy of the implants, as described by Adams et al. (2002). Uteri were removed by cutting at a specified distance along the uterine horns and just caudal from where the horns join. Uteri were gently blotted to remove excess fluid and weighed. Uterine weight was normalized to body weight.

\section{Statistical analysis}

Results are expressed as mean \pm SEM. Data from electrophysiological analysis, ISH, RIA, and uterine weights were analyzed using a two-way ANOVA with a Tukey post hoc multiple comparison. Statistical analyses were performed with SigmaStat (Systat).

\section{Results}

\section{Systemic effects of E2}

In the present study, OVX resulted in similar circulating levels of E2 $(\sim 6 \mathrm{pg} / \mathrm{ml})$ in vehicle-treated young and aged control rats and were approximately twofold greater in the corresponding young and aged OVX groups treated with E2 (Fig. 2A). These replacement levels of E2 are comparable with those in previous studies and are considered to be in a low physiological range (Dubal et al., 1998). Aged female F344 rats are in an acyclic, persistent diestrus state (Estes et al., 1982; Sone et al., 2007) characterized by low E2 levels. E2 levels in 21-22-month-old F344 rats, equivalent to rats used in our study, are reported to be $\sim 6-10 \mathrm{pg} / \mathrm{ml}$ in intact rats (Markowska and Savonenko, 2002; Bowman et al., 2006) and $\sim 6$ $\mathrm{pg} / \mathrm{ml}$ in OVX rats (Markowska and Savonenko, 2002). By comparison, young cycling F344s have peak E2 levels of $\sim 70 \mathrm{pg} / \mathrm{ml}$ during proestrus (Haim et al., 2003).

Confirming E2 action in vivo, uterine weight in both young and aged E2-treated animals was approximately threefold greater than that of controls (Fig. 2B). Compared with other tissues, the uterus contains a relatively high number of ERs, and thus, a bioassay of the uterotrophic effects of E2 is considered a highly sensitive test and a positive control for demonstrating E2 action in vivo (Adams et al., 2002; Erben et al., 2004).

Differences in animal weight were also observed in response to age and E2 treatment. As seen in the control groups, animal weight significantly increased in an age-dependent manner. 

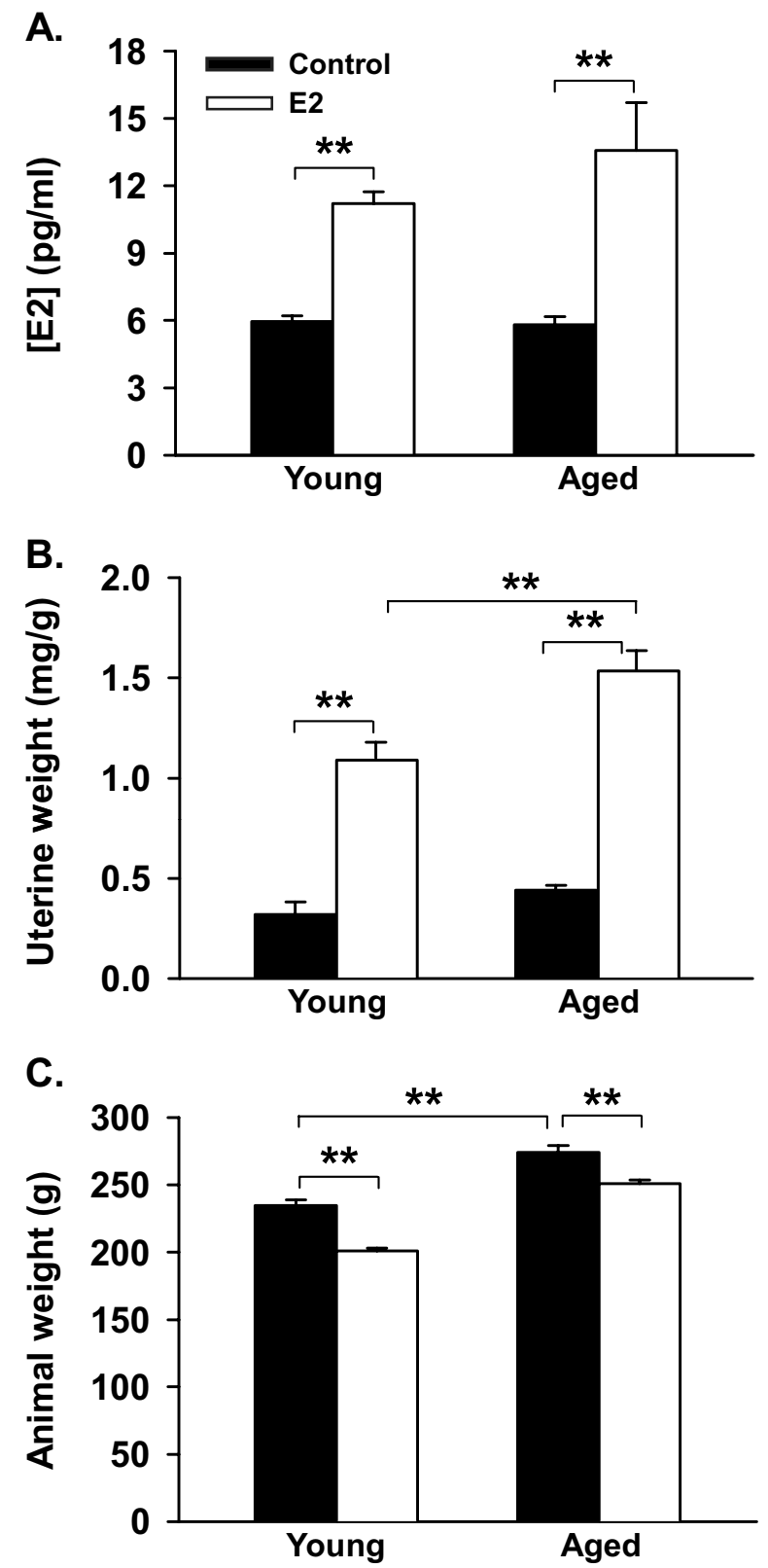

Figure 2. Bioassay of systemic effects of E2 implants. Comparison of vehicle and E2 treatment on plasma E2 levels, uterine weight, and animal weight in young and aged OVX F344 rats. $A$, E2 plasma levels were greater in E2-treated compared with vehicle-treated animals in both young and aged animals $\left(F_{(1,16)}=33.6 ; p<0.001\right)$. B , Uteri were responsive to $\mathrm{E} 2$ implants. Uterine weight, which was normalized to body weight, increased by at least threefold in response to $\mathrm{E} 2$ treatment in both young and aged animals $\left(F_{(1,16)}=129 ; p<0.001\right)$. Within the E2-treated group, uteri were larger in aged than in younger animals. $C$, Animal weight was significantly affected by age $\left(F_{(1,16)}=141 ; p<0.001\right)$ and $\mathrm{E} 2$ treatment $\left(F_{(1,16)}=57 ; p<\right.$ $0.001)$. E2 treatment resulted in a significant decrease in young and aged animals compared with their age-matched control group. Figure legend in $\boldsymbol{A}$ also applies to $\boldsymbol{B}$ and $\boldsymbol{C}$. Data are mean \pm SEM; post hoc analysis, ${ }^{* *} p \leq 0.01$.

However, E2 treatment significantly decreased the weight of both young and aged animals compared with their aged-matched controls (Fig. 2C). The effect of E2 and ERs on body weight is well recognized (Wade, 1986; Heine et al., 2000) and believed to occur via multiple mechanisms, including a reduction in food intake and the expression of lipogenic genes (Cooke and Naaz, 2004; D'Eon et al., 2005). Conversely, the OVX rodent model of menopause is characterized by weight gain (Simpkins et al., 1988), which is preventable by treatment with E2 (Meli et al., 2004). These effects on body weight in rodents are similar to those reported to occur with human menopause (Sowers et al., 2007).

\section{Effect of E2 on LTCCs in young and aged OVX rats}

The effect of chronic E2 and vehicle treatment in young and aged OVX rats on LTCC current was determined by recording LTCC activity from the cell bodies of hippocampal CA1 pyramidal neurons using the zipper slice preparation (Fig. 1C). Multichannel LTCC currents were isolated in cell-attached patch-clamp recordings by using the LTCC agonist ( \pm )BayK8644. Representative current traces of LTCC activity from each treatment group are shown in Figure $3 A$. The average patch current determined from the ensembles for each treatment group is shown in Figure $3 B(n=12-15$ cells/group). The average current activity of aged OVX controls increased by $\sim 70 \%$ relative to the young OVX controls $\left(F_{(1,48)}=4.38, p<0.05\right)$, indicating an age-related difference. However, in E2-treated aged OVX animals, LTCC currents were decreased by $\sim 45 \%$ compared with the aged control group $\left(F_{(1,48)}=4.55, p<0.05\right)$. Thus, LTCC currents resulting from the $\mathrm{E} 2$ treatment in aged animals more closely resembled currents observed in young controls. LTCC currents from E2treated young OVX animals were reduced by $\sim 45 \%$ relative to the young control group, but this reduction was not significant $(p=0.3)$.

The $I-V$ relationship was examined for each patch to determine if age or E2 treatment altered the voltage dependence of the LTCC ( $n=10-12$ cells/group) (Fig. 4$)$. The voltage at which the maximal current $(0 \mathrm{mV})$ and the half-maximal activation voltages occurred were similar for all treatment groups $(-18.3$ to $-20.0 \mathrm{mV}$ ). These parameters are characteristic of LTCCs and are similar to values reported previously (Thibault and Landfield, 1996; Brewer et al., 2001). Thus, E2 treatment in the aged animals reduced LTCC current activity without altering voltage dependence.

\section{In situ hybridization}

The effects of age and $\mathrm{E} 2$ treatment on $\mathrm{Ca}_{\mathrm{v}} 1.2$ and $\mathrm{Ca}_{\mathrm{v}} 1.3$ gene expression in the CA1 region of the hippocampus were determined using ISH. This approach made it possible to conduct a quantitative analysis of gene expression using film autoradiograms of the cell body layer of the CA1 region (stratum pyramidale), the same region from which patched neurons were recorded. Consistent with other studies (Herman et al., 1998; Clark et al., 2003), we found that $\mathrm{Ca}_{\mathrm{v}} 1.2$ subunit expression was more robust in the dentate gyrus (DG) and CA3 regions than in the $\mathrm{CA} 1$, but $\mathrm{Ca}_{\mathrm{v}} 1.3$ expression was more robust in the DG and more uniform in CA3 and CA1 regions (Fig. 5A).

Within the CA1 region of stratum pyramidale, E2 treatment of aged animals significantly decreased $(\sim 17 \%) \mathrm{Ca}_{\mathrm{v}} 1.2 \mathrm{mRNA}$ expression $\left(F_{(1,15)}=4.3 ; p=0.02\right)$ (Fig. $\left.5 B\right)$. In the young animals, E2 treatment also reduced $\mathrm{Ca}_{\mathrm{v}} 1.2$ expression ( $\left.\sim 9 \%\right)$, but this decrease was not significant. E2 treatment did not affect mRNA expression of the $\mathrm{Ca}_{\mathrm{v}} 1.3$ subunit in either the young or aged animals compared with their age-matched controls (Fig. $5 C)$. Additionally, there were no age-related changes in either $\mathrm{Ca}_{\mathrm{v}} 1.2$ or $\mathrm{Ca}_{\mathrm{v}} 1.3$ expression.

\section{Discussion}

Two potentially important findings regarding LTCC activity in female rats were identified in this study. First, similar to reports in aged male rats (Thibault and Landfield, 1996; L. D. Brewer et al., 2006), LTCC currents were increased in hippocampal CA1 neu- 
rons from aged OVX rats. Aged females, therefore, appear as susceptible to changes in this prominent $\mathrm{Ca}^{2+}$ influx pathway. Second, LTCC currents from a similar group of aged females treated chronically with a low physiological dose of E2 were of smaller magnitude and comparable with those observed in younger female rats. These results suggest a mechanism by which LTCCs are tonically inhibited by circulating E2 in young animals. This inhibition, however, may be lost when E2 levels are very low (e.g., aging and reproductive senescence). Although intact females were not included in this study, 21-22month-old intact and OVX F344 rats appear to have similarly low levels of E2 (Markowska and Savonenko, 2002; Bowman et al., 2006). We also found that E2 reduced LTCC activity in the young OVX females, albeit nonsignificantly. Perhaps LTCCs are affected by E2 loss, regardless of age. The impact on LTCCs, however, may be greater in aged animals because of the prolonged absence of E2 during reproductive senescence.

Given that the results of the present study show that E2 reduces LTCCs, perhaps E2 acts as an endogenous modulator of LTCCs and attenuates the impact of age-related $\mathrm{Ca}^{2+}$ dyshomeostasis, cognitive decline, and vulnerability to neuropathologies (Toescu et al., 2004; Disterhoft and Oh, 2006; Foster, 2007). Thus, some of the beneficial effects of E2 and hormone replacement therapy (HRT) on the brain (Wise et al., 2005; Sherwin and Henry, 2008; Simpkins and Singh, 2008; Spencer et al., 2008) may be attributed to modulation of LTCCs by E2. Our results are also consistent with studies demonstrating E2 modulation of several $\mathrm{Ca}^{2+}$-dependent processes, particularly those associated with cognition (Boulware et al., 2005; Liu et al., 2008) and neuroprotection (G. J. Brewer et al., 2006; Gamerdinger et al., 2006; Zhao and Brinton, 2007). Of course, E2 exerts neuroprotective and nootropic actions by various mechanisms (Dubal and Wise, 2001; Nilsen and Brinton, 2003; Yang et al., 2004; Scharfman and Maclusky, 2005; Wu et al., 2005; Dziennis et al., 2007; Simpkins and Singh, 2008) and its effect on LTCCs represents only one component of its potentially beneficial effects (Sherwin and Henry, 2008).

\section{LTCCs and $\mathrm{Ca}^{2+}$ dyshomeostasis in aging}

The age-related increase in LTCC current is a biomarker of brain aging (Landfield, 1987; Foster, 2007; Thibault et al., 2007) and is associated with impaired cognitive performance in the Morris water maze (Thibault and Landfield, 1996). The increased influx of $\mathrm{Ca}^{2+}$ via LTCCs affects numerous $\mathrm{Ca}^{2+}$-dependent processes, including the AHP, $\mathrm{Ca}^{2+}$-induced $\mathrm{Ca}^{2+}$ release, synaptic plastic-
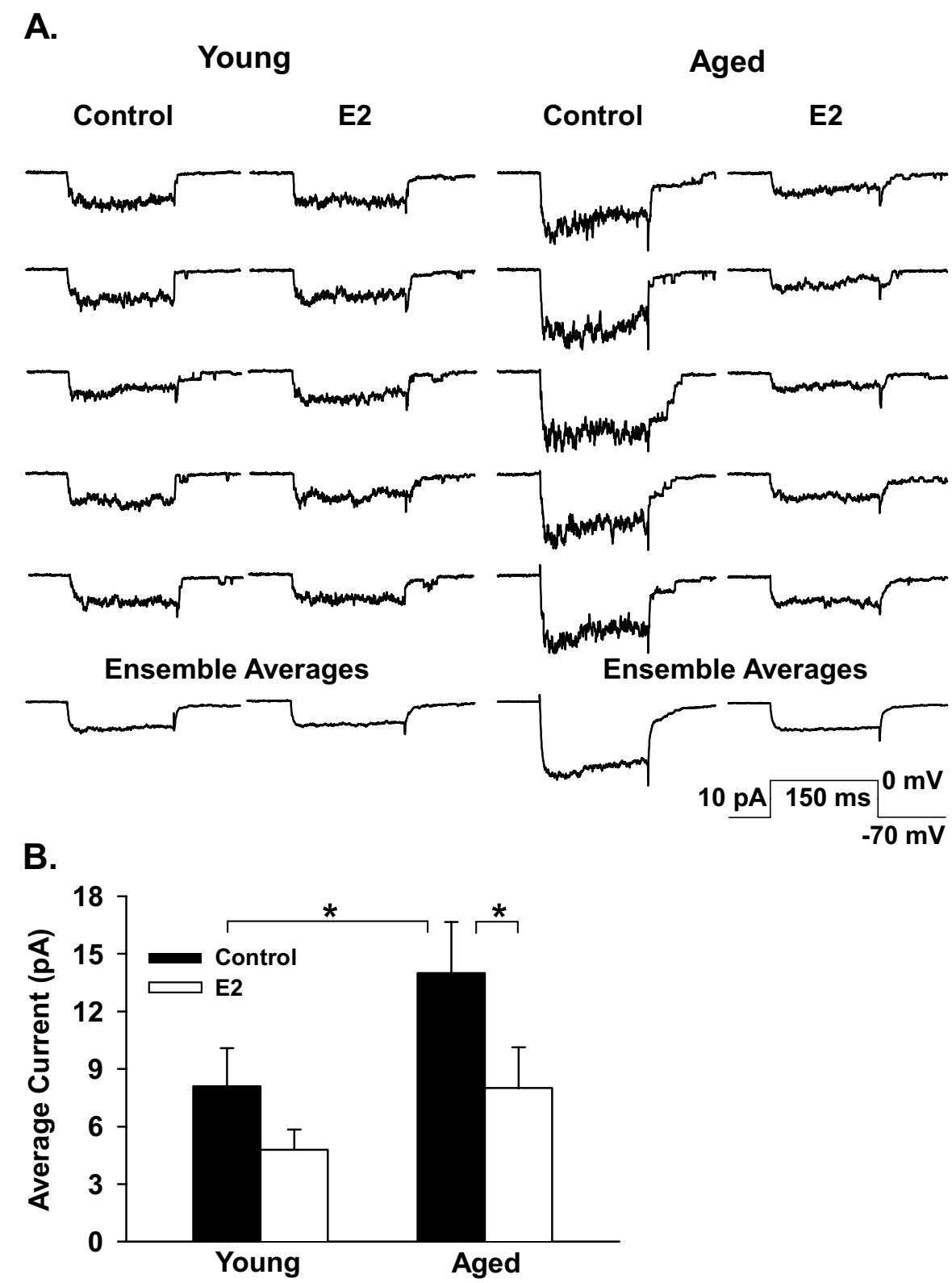

Figure 3. LTCC current activity from young and aged OVX rats chronically treated with either vehicle or E2. Patch currents were recorded from the cell body membranes of hippocampal pyramidal CA1 neurons using multichannel patch pipettes. $\boldsymbol{A}$, Five representative current traces are shown from each treatment group. Currents were evoked by depolarizing to $0 \mathrm{mV}$ from a -70 $\mathrm{mV}$ holding potential. Ensemble averages for each patch are also shown and were obtained from 15 depolarizations. LTCC currents from aged controls were larger than those of young controls. However, LTCC current activity was reduced in the aged animals treated with E2. $\boldsymbol{B}$, Average patch currents obtained from ensemble averages for each treatment group (mean \pm SEM). Aged controls had significantly larger LTCC currents than young controls. However, in the aged animals, E2 treatment significantly reduced the average ensemble currents. ${ }^{*} p \leq 0.05, n=12-15$ cells per/group; four animals per group.

ity, and LTCC-mediated gene expression (Landfield and Pitler, 1984; Moyer et al., 1992; Deupree et al., 1993; Norris et al., 1998; Thibault et al., 2001; Deisseroth et al., 2003; Gant et al., 2006). Additionally, increased LTCCs with brain aging can lead indirectly to an increased probability of action potential failure. The increase in LTCCs enhances the $\mathrm{Ca}^{2+}$-dependent AHP, reducing neuronal firing and excitability (Disterhoft and Oh, 2006; Abraham, 2008; Gant and Thibault, 2008). However, if LTCCs in aged neurons are blocked with DHPs, various forms of synaptic plasticity and cognitive performance are enhanced (Deyo et al., 1989; Norris et al., 1998; Thibault et al., 2001; Veng et al., 2003). Interestingly, a recent study of an elderly cohort with hypertension 


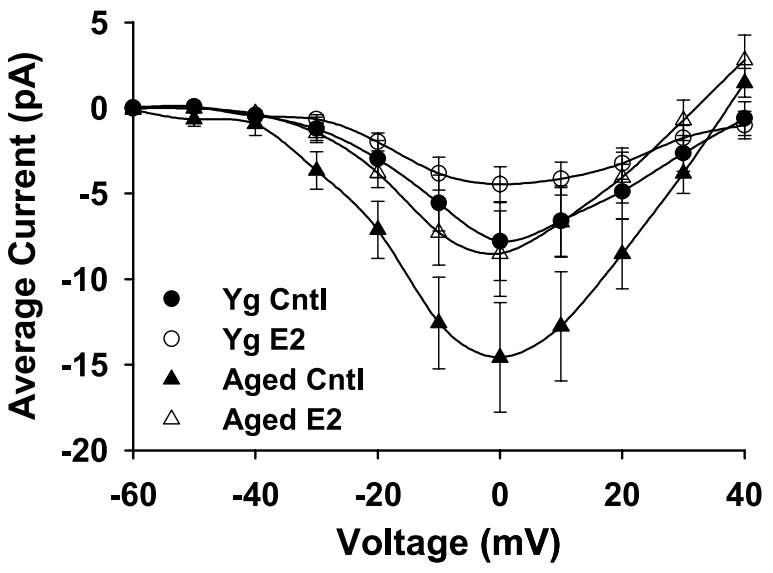

Figure 4. I-V relationship according to age and treatment. LTCC patch currents were evoked by depolarizing in $+10 \mathrm{mV}$ increments from a $-70 \mathrm{mV}$ holding potential to $+40 \mathrm{mV}$. Results are shown as average patch current (mean \pm SEM). The $I-V$ relationship was not changed by E2 treatment in either young $(\mathrm{yg})$ or aged $0 \mathrm{VX}$ animals relative to controls (cnt)). The half-maximal activation voltages (approximately -18 to $-20 \mathrm{mV}$ ) and the stimulus voltage at which maximal current amplitude occurred $(0 \mathrm{mV})$ were similar for all treatment groups. However, similar to the ensemble averages (Fig. 3), currents were much greater in the aged controls than the young controls, and E2 treatment reduced currents in the aged animals. $n=10-12$ cells per/group; four animals per group.

showed slower rates of cognitive decline among those on $\mathrm{Ca}^{2+}$ channel blockers versus other antihypertensive agents. Because all agents reduced blood pressure to a similar extent, cognitive preserving effects were attributed to reduced neuronal LTCC influx (Trompet et al., 2008).

In the present study, E2 reduced body weight, raising the possibility that $\mathrm{E} 2$ mimics the effects of caloric restriction (CR). CR reduces biomarkers of brain aging (Patel and Finch, 2002), including changes in age-related $\mathrm{Ca}^{2+}$-dependent mechanisms (Hemond and Jaffe, 2005). In rodents, CR typically is initiated in young adulthood and maintained for the entire lifespan, resulting in $\sim 40-50 \%$ body weight reduction (Turturro et al., 1999). Whether several weeks of E2 with a much smaller weight loss (8-17\%) (Fig. 2C) elicit effects characteristic of lifelong CR remains to be determined. Nevertheless, $\mathrm{CR}$ and $\mathrm{E} 2$ target common nutrient-signaling pathways (D'Eon et al., 2005; Mair and Dillin, 2008), and a recent study in humans shows that even short-term CR in the elderly can improve memory (Witte et al., 2009).

\section{Potential mechanism of E2 regulation of LTCCs}

To identify a possible mechanism underlying the E2-mediated reduction in current in aged female neurons, mRNA expression of $\mathrm{Ca}_{\mathrm{v}} 1.2$ and $\mathrm{Ca}_{\mathrm{v}} 1.3$ pore-forming subunits was determined. Prior studies examining either mRNA or protein expression in aged male rats have shown either no effect (Kelly et al., 2001) or an increase in one or both LTCC subunits (Herman et al., 1998; Veng and Browning, 2002; Veng et al., 2003). In the present study, ISH was used to examine mRNA expression in the stratum pyramidale of the CA1 region, the region from which we recorded LTCCs in the hippocampal zipper slices. We did not find an age-related change in mRNA expression of either $\mathrm{Ca}_{\mathrm{v}} 1.2$ or $\mathrm{Ca}_{\mathrm{v}} 1.3$ subunits. However, E2 treatment in aged rats selectively reduced $\mathrm{Ca}_{\mathrm{v}} 1.2$ mRNA expression by $\sim 17 \%$, although this was not to the extent of the approximate twofold reduction in LTCC current seen with E2. It should be noted that the proportional relationship between gene expression and functional measures of LTCC activity are unknown, and E2 may affect posttranslational modifications and protein-protein interactions to modulate

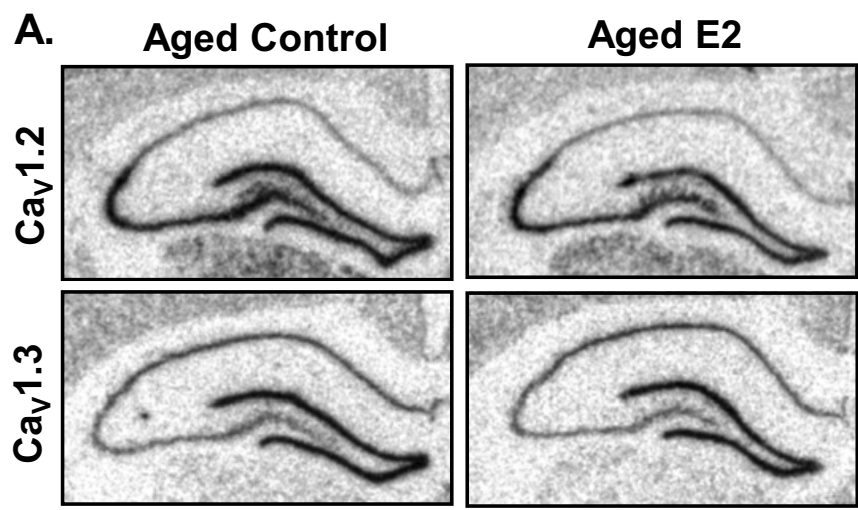

B.

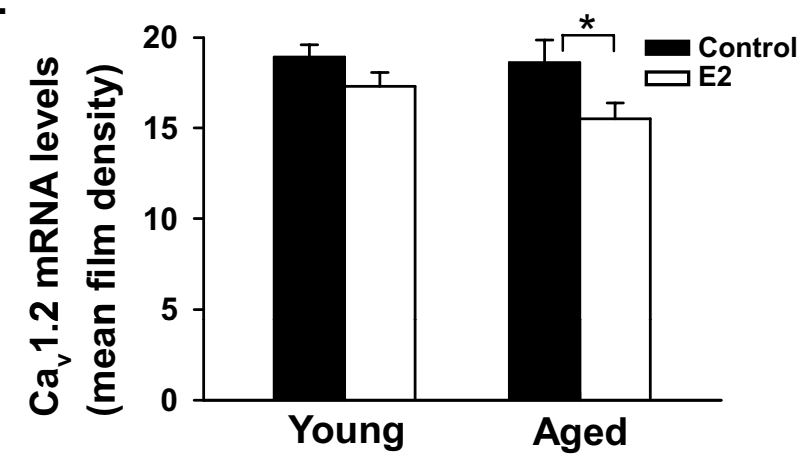

C.

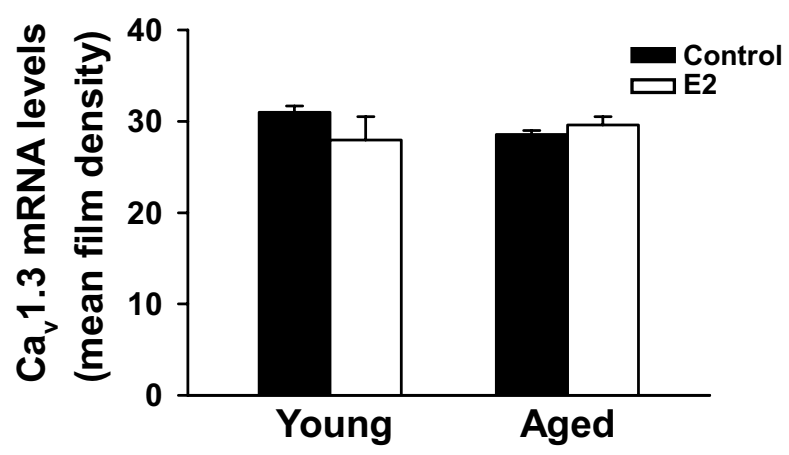

Figure 5. ISH analysis of $\mathrm{Ca}_{\mathrm{v}} 1.2$ and $\mathrm{Ca}_{\mathrm{v}} 1.3 \mathrm{mRNA}$ expression in the CA1 region of the hippocampus from control and $\mathrm{E} 2$-treated animals. $A$, Representative images of $\mathrm{Ca}_{\mathrm{v}} 1.2$ and $\mathrm{Ca}_{\mathrm{v}} 1.3$ mRNA expression in the hippocampus of aged-OVX female rats treated with vehicle or E2. Intensity of $\mathrm{Ca}_{\mathrm{v}} 1.2 \mathrm{mRNA}$ labeling in the CA1 region showed a small but significant reduction in response to $\mathrm{E} 2$ treatment compared with vehicle control. $\mathrm{Ca}_{\mathrm{v}} 1.3 \mathrm{mRNA}$ was not affected by $\mathrm{E} 2$ treatment. Images were derived from film autoradiograms after ISH in which cRNA probes were applied to coronal sections. Sense controls for cDNA probes were applied to adjacent sections and produced a negligible hybridization signal (data not shown). $\boldsymbol{B}$, E2 treatment significantly decreased $\mathrm{Ca}_{v} 1.2$ expression levels in aged animals ( ${ }^{*} p=0.02$ ) but not young animals. mRNA levels in the CA1 region were measured using optical density of film autoradiograms. C, E2 treatment did not significantly affect $\mathrm{Ca}_{\mathrm{v}} 1.3$ expression levels in either young or aged animals. Data are mean \pm SEM; $n=4-5$ animals/group.

channel function (Davare and Hell, 2003; Kobayashi et al., 2007; Norris et al., 2008). Furthermore, the fact that E2, but not aging, affected mRNA expression suggests that aging and E2 modulate this channel via different mechanisms. Nonetheless, our results suggest that $\mathrm{Ca}_{\mathrm{v}} 1.2$ is a likely target of $\mathrm{E} 2$ action in the brain and that E2's mechanism of action may involve, at least in part, a suppression of LTCC mRNA expression.

\section{$\mathrm{Ca}_{\mathrm{v}} 1.2$ : a target of E2}

It is interesting that $\mathrm{E} 2$ reduced expression of $\mathrm{Ca}_{\mathrm{v}} 1.2$ in aged females, because this LTCC subtype has distinct properties from 
$\mathrm{Ca}_{\mathrm{v}} 1.3$ (Catterall et al., 2005). For example, $\mathrm{Ca}_{\mathrm{v}} 1.2$ is selectively blocked by lower concentrations of DHPs (Catterall et al., 2005) and can be internalized during excessive activation (Green et al., 2007). Additionally, a phosphorylation-dependent increase specifically in the activity of $\mathrm{Ca}_{\mathrm{v}} 1.2$ (Davare and Hell, 2003) contributes to age-related increases in LTCCs and $\mathrm{Ca}^{2+}$ influx in male rats (Thibault and Landfield, 1996; Thibault et al., 2001). A subpopulation of $\mathrm{Ca}_{\mathrm{v}} 1.2 \mathrm{~s}$ also form signaling complexes in neuronal membrane caveolae (Balijepalli et al., 2006), sites of membranebound ERs (Luoma et al., 2008). Together, these results suggest that a high degree of regulation has evolved to control LTCC activity and maintain optimal intracellular concentrations of $\mathrm{Ca}^{2+}$.

Further support for a distinct role of $\mathrm{Ca}_{\mathrm{v}} 1.2$ comes from studies of LTP. LTP is dependent on $\mathrm{Ca}^{2+}$ influx via NMDARs and LTCCs (Grover and Teyler, 1990) and consists of early and late LTP phases. Recently, Huang and Kandel (2006) described a novel form of late-LTP that steadily increases with age, is elicited by low-frequency stimulation, and is blocked by DHPs. Furthermore, this form of late-LTP may be an important underlying factor contributing to age-related memory impairment. Interestingly, $\mathrm{Ca}_{\mathrm{v}} 1.2$ may participate in late-LTP and spatial learning (Moosmang et al., 2005). Given that E2 can reduce LTCCs and target $\mathrm{Ca}_{\mathrm{v}} 1.2 \mathrm{~s}$ in aged female brain, E2 may prevent an agerelated increase in a form of synaptic plasticity associated with memory impairment. Indeed, we have observed that E2 treatment decreases LTCC-dependent LTP and improves cognitive performance in mid-aged female rats (J. T. Rogers and N. M. Porter, unpublished observations). Furthermore, the E2-related reduction in LTCCs may shift the balance between NMDAR and LTCC forms of LTP to favor the NMDAR-dependent form. Our results, together with others, suggest this may lead to enhanced LTP in the aging female brain exposed to E2 (Foy et al., 2008).

Because in vivo treatment with $\mathrm{E} 2$ was chronic, genomic mechanisms likely contributed to the E2 effects. Further support comes from ERKO mice which have larger LTCC currents in isolated cardiac myoctes (Johnson et al., 1997). Although we cannot rule out a rapid effect of E2 (Kelly and Rønnekleiv, 2008), LTCC recordings were obtained from hippocampal zipper slices bathed in media lacking E2. Rapid modulation of LTCCs has been reported in vitro, and depending on conditions, E2 can either stimulate (Wu et al., 2005; Sarkar et al., 2008) or inhibit $\mathrm{Ca}^{2+}$ influx (Mermelstein et al., 1996; Kurata et al., 2001; Boulware et al., 2005; Ullrich et al., 2007). These results suggest complex E2 regulation of LTCCs that may be concentration-, cell type-, age-, and even gender-dependent. Nonetheless, our study addresses a key issue regarding E2 action in the aged brain, whether E2 retains the ability to modulate some targets after a prolonged absence (Morrison et al., 2006). The present results suggest that E2 may prevent or reduce age-related $\mathrm{Ca}^{2+}$ dyshomeostasis by regulating LTCCs and offer some degree of neuroprotection even at advanced age. Although this late administration may not represent optimal timing for treatment initiation (Suzuki et al., 2007; Brinton, 2008; Sherwin and Henry, 2008), our studies also demonstrated benefit derived from a low physiological dose of E2. With continuing refinement of dosage in humans, HRT may safely attenuate CNS complications of menopause and pose minimal risk to an appropriately identified female population. Whether E2 has a unique gender-specific role in modulating LTCCs in vivo is unknown, although the results of Johnson et al. (1997) suggest otherwise. The development of nonfeminizing E2 analogs (Simpkins et al., 2005) or brain selective E2-like compounds (Zhao et al., 2007) may provide an opportunity to use these agents broadly (Toung et al., 1998), regardless of gender, to take advantage of potential age-reversing E2 effects.

\section{References}

Abraham WC (2008) Metaplasticity: tuning synapses and networks for plasticity. Nat Rev Neurosci 9:387-399.

Adams MM, Fink SE, Shah RA, Janssen WG, Hayashi S, Milner TA, McEwen BS, Morrison JH (2002) Estrogen and aging affect the subcellular distribution of estrogen receptor- $\alpha$ in the hippocampus of female rats. J Neurosci 22:3608-3614.

Balijepalli RC, Foell JD, Hall DD, Hell JW, Kamp TJ (2006) Localization of cardiac L-type $\mathrm{Ca}(2+)$ channels to a caveolar macromolecular signaling complex is required for beta(2)-adrenergic regulation. Proc Natl Acad Sci U S A 103:7500-7505.

Behl C (2002) Oestrogen as a neuroprotective hormone. Nat Rev Neurosci 3:433-442.

Bi R, Foy MR, Vouimba RM, Thompson RF, Baudry M (2001) Cyclic changes in estradiol regulate synaptic plasticity through the MAP kinase pathway. Proc Natl Acad Sci U S A 98:13391-13395.

Blalock EM, Chen KC, Vanaman TC, Landfield PW, Slevin JT (2001) Epilepsy-induced decrease of L-type Ca2 + channel activity and coordinate regulation of subunit mRNA in single neurons of rat hippocampal 'zipper' slices. Epilepsy Res 43:211-226.

Boulware MI, Weick JP, Becklund BR, Kuo SP, Groth RD, Mermelstein PG (2005) Estradiol activates group I and II metabotropic glutamate receptor signaling, leading to opposing influences on cAMP response elementbinding protein. J Neurosci 25:5066-5078.

Bowman RE, Maclusky NJ, Diaz SE, Zrull MC, Luine VN (2006) Aged rats: sex differences and responses to chronic stress. Brain Res 1126:156-166.

Brewer GJ, Reichensperger JD, Brinton RD (2006) Prevention of age-related dysregulation of calcium dynamics by estrogen in neurons. Neurobiol Aging 27:306-317.

Brewer LD, Thibault V, Chen KC, Langub MC, Landfield PW, Porter NM (2001) Vitamin D hormone confers neuroprotection in parallel with downregulation of L-type calcium channel expression in hippocampal neurons. J Neurosci 21:98-108.

Brewer LD, Porter NM, Kerr DS, Landfield PW, Thibault O (2006) Chronic lalpha, 25- $(\mathrm{OH})(2)$ vitamin $\mathrm{D}(3)$ treatment reduces $\mathrm{Ca}(2+)$-mediated hippocampal biomarkers of aging. Cell Calcium 40:277-286.

Brewer LD, Thibault O, Staton J, Thibault V, Rogers JT, Garcia-Ramos G, Kraner S, Landfield PW, Porter NM (2007) Increased vulnerability of hippocampal neurons with age in culture: temporal association with increases in NMDA receptor current, NR2A subunit expression and recruitment of L-type calcium channels. Brain Res 1151:20-31.

Brinton RD (2008) The healthy cell bias of estrogen action: mitochondrial bioenergetics and neurological implications. Trends Neurosci 31:529-537.

Burke SN, Barnes CA (2006) Neural plasticity in the ageing brain. Nat Rev Neurosci 7:30-40.

Cahill L (2006) Why sex matters for neuroscience. Nat Rev Neurosci 7:477-484.

Carrer HF, Araque A, Buño W (2003) Estradiol regulates the slow $\mathrm{Ca}^{2+}$ activated $\mathrm{K}^{+}$current in hippocampal pyramidal neurons. J Neurosci 23:6338-6344.

Catterall WA, Perez-Reyes E, Snutch TP, Striessnig J (2005) International union of pharmacology. XLVIII. Nomenclature and structure-function relationships of voltage-gated calcium channels. Pharmacol Rev 57:411-425.

Clark NC, Nagano N, Kuenzi FM, Jarolimek W, Huber I, Walter D, Wietzorrek G, Boyce S, Kullmann DM, Striessnig J, Seabrook GR (2003) Neurological phenotype and synaptic function in mice lacking the CaV1.3 alpha subunit of neuronal L-type voltage-dependent $\mathrm{Ca} 2+$ channels. Neuroscience 120:435-442.

Cooke PS, Naaz A (2004) Role of estrogens in adipocyte development and function. Exp Biol Med (Maywood) 229:1127-1135.

Coon AL, Wallace DR, Mactutus CF, Booze RM (1999) L-type calcium channels in the hippocampus and cerebellum of Alzheimer's disease brain tissue. Neurobiol Aging 20:597-603.

Davare MA, Hell JW (2003) Increased phosphorylation of the neuronal L-type $\mathrm{Ca}(2+)$ channel Ca. (v) 1.2 during aging. Proc Natl Acad Sci U S A 100:16018-16023. 
Degen GH, Janning P, Diel P, Bolt HM (2002) Estrogenic isoflavones in rodent diets. Toxicol Lett 128:145-157.

Deisseroth K, Mermelstein PG, Xia H, Tsien RW (2003) Signaling from synapse to nucleus: the logic behind the mechanisms. Curr Opin Neurobiol 13:354-365.

D’Eon TM, Souza SC, Aronovitz M, Obin MS, Fried SK, Greenberg AS (2005) Estrogen regulation of adiposity and fuel partitioning. Evidence of genomic and non-genomic regulation of lipogenic and oxidative pathways. J Biol Chem 280:35983-35991.

Desmond NL, Levy WB (1997) Ovarian steroidal control of connectivity in the female hippocampus: an overview of recent experimental findings and speculations on its functional consequences. Hippocampus 7:239-245.

Deupree DL, Bradley J, Turner DA (1993) Age-related alterations in potentiation in the CA1 region in F344 rats. Neurobiol Aging 14:249-258.

Deyo RA, Straube KT, Disterhoft JF (1989) Nimodipine facilitates associative learning in aging rabbits. Science 243:809-811.

Disterhoft JF, Oh MM (2006) Pharmacological and molecular enhancement of learning in aging and Alzheimer's disease. J Physiol Paris 99:180-192.

Dowling AL, Martz GU, Leonard JL, Zoeller RT (2000) Acute changes in maternal thyroid hormone induce rapid and transient changes in gene expression in fetal rat brain. J Neurosci 20:2255-2265.

Dubal DB, Wise PM (2001) Neuroprotective effects of estradiol in middleaged female rats. Endocrinology 142:43-48.

Dubal DB, Kashon ML, Pettigrew LC, Ren JM, Finklestein SP, Rau SW, Wise PM (1998) Estradiol protects against ischemic injury. J Cereb Blood Flow Metab 18:1253-1258.

Dziennis S, Jia T, Rønnekleiv OK, Hurn PD, Alkayed NJ (2007) Role of signal transducer and activator of transcription-3 in estradiol-mediated neuroprotection. J Neurosci 27:7268-7274.

Erben RG, Brunner KS, Breig B (2004) Long-term sensitivity of uterus and hypothalamus/pituitary axis to 17beta-estradiol is higher than that of bone in rats. J Bone Miner Res 19:1827-1832.

Estes KS, Simpkins JW, Kalra SP (1982) Normal LHRH neuronal function and hyperprolactinemia in old pseudopregnant Fischer 344 rats. Neurobiol Aging 3:247-252.

Foster TC (2007) Calcium homeostasis and modulation of synaptic plasticity in the aged brain. Aging Cell 6:319-325.

Fox AP, Nowycky MC, Tsien RW (1987) Single-channel recordings of three types of calcium channels in chick sensory neurones. J Physiol 394:173-200.

Foy MR, Xu J, Xie X, Brinton RD, Thompson RF, Berger TW (1999) 17betaestradiol enhances NMDA receptor-mediated EPSPs and long-term potentiation. J Neurophysiol 81:925-929.

Foy MR, Baudry M, Foy JG, Thompson RF (2008) 17beta-estradiol modifies stress-induced and age-related changes in hippocampal synaptic plasticity. Behav Neurosci 122:301-309.

Gamerdinger M, Manthey D, Behl C (2006) Oestrogen receptor subtypespecific repression of calpain expression and calpain enzymatic activity in neuronal cells-implications for neuroprotection against Ca-mediated excitotoxicity. J Neurochem 97:57-68.

Gant JC, Thibault O (2008) Action potential throughput in aged rat hippocampal neurons: regulation by selective forms of hyperpolarization. Neurobiol Aging. Advance online publication. Retrieved March 24, 2008. doi:10.1016/j.neurobiolaging.2008.02.006.

Gant JC, Sama MM, Landfield PW, Thibault O (2006) Early and simultaneous emergence of multiple hippocampal biomarkers of aging is mediated by $\mathrm{Ca}^{2+}$-induced $\mathrm{Ca}^{2+}$ release. J Neurosci 26:3482-3490.

Good M, Day M, Muir JL (1999) Cyclical changes in endogenous levels of oestrogen modulate the induction of LTD and LTP in the hippocampal CA1 region. Eur J Neurosci 11:4476-4480.

Gould E, Woolley CS, Frankfurt M, McEwen BS (1990) Gonadal steroids regulate dendritic spine density in hippocampal pyramidal cells in adulthood. J Neurosci 10:1286-1291.

Gray R, Johnston D (1987) Noradrenaline and beta-adrenoceptor agonists increase activity of voltage-dependent calcium channels in hippocampal neurons. Nature 327:620-622.

Gray R, Fisher R, Spruston N, Johnston D (1990) Acutely exposed hippocampal neurons: a preparation for patch clamping neurons from adult hippocampal slices. In: Preparations of vertebrate central nervous system in vitro, Ed 1 (Jahnsen H, ed), pp 3-24. New York: Wiley.

Green EM, Barrett CF, Bultynck G, Shamah SM, Dolmetsch RE (2007) The tumor suppressor eIF3e mediates calcium-dependent internalization of the L-type calcium channel CaV1.2. Neuron 55:615-632.

Grover LM, Teyler TJ (1990) Two components of long-term potentiation induced by different patterns of afferent activation. Nature 347:477-479.

Haim S, Shakhar G, Rossene E, Taylor AN, Ben-Eliyahu S (2003) Serum levels of sex hormones and corticosterone throughout 4- and 5-day estrous cycles in Fischer 344 rats and their simulation in ovariectomized females. J Endocrinol Invest 26:1013-1022.

Hamill OP, Marty A, Neher E, Sakmann B, Sigworth FJ (1981) Improved patch-clamp techniques for high-resolution current recording from cells and cell-free membrane patches. Pflugers Arch 391:85-100.

Hao J, Janssen WG, Tang Y, Roberts JA, McKay H, Lasley B, Allen PB, Greengard P, Rapp PR, Kordower JH, Hof PR, Morrison JH (2003) Estrogen increases the number of spinophilin-immunoreactive spines in the hippocampus of young and aged female rhesus monkeys. J Comp Neurol 465:540-550.

Heine PA, Taylor JA, Iwamoto GA, Lubahn DB, Cooke PS (2000) Increased adipose tissue in male and female estrogen receptor-alpha knockout mice. Proc Natl Acad Sci U S A 97:12729-12734.

Hemond P, Jaffe DB (2005) Caloric restriction prevents aging-associated changes in spike-mediated $\mathrm{Ca} 2+$ accumulation and the slow afterhyperpolarization in hippocampal CA1 pyramidal neurons. Neuroscience 135:413-420.

Herman JP, Chen KC, Booze R, Landfield PW (1998) Up-regulation of alpha1D Ca2 + channel subunit mRNA expression in the hippocampus of aged F344 rats. Neurobiol Aging 19:581-587.

Huang YY, Kandel ER (2006) Age-related enhancement of a protein synthesis-dependent late phase of LTP induced by low frequency pairedpulse stimulation in hippocampus. Learn Mem 13:298-306.

Hurn PD, Macrae IM (2000) Estrogen as a neuroprotectant in stroke. J Cereb Blood Flow Metab 20:631-652.

Johnson BD, Zheng W, Korach KS, Scheuer T, Catterall WA, Rubanyi GM (1997) Increased expression of the cardiac L-type calcium channel in estrogen receptor-deficient mice. J Gen Physiol 110:135-140.

Juraska JM (1991) Sex differences in "cognitive" regions of the rat brain. Psychoneuroendocrinology 16:105-109.

Kelly KM, Kume A, Albin RL, Macdonald RL (2001) Autoradiography of L-type and $\mathrm{N}$-type calcium channels in aged rat hippocampus, entorhinal cortex, and neocortex. Neurobiol Aging 22:17-23.

Kelly MJ, Rønnekleiv OK (2008) Membrane-initiated estrogen signaling in hypothalamic neurons. Mol Cell Endocrinol 290:14-23.

Kelly MJ, Kuhnt U, Wuttke W (1980) Hyperpolarization of hypothalamic parvocellular neurons by 17 beta-estradiol and their identification through intracellular staining with procion yellow. Exp Brain Res 40:440-447.

Kobayashi T, Yamada Y, Fukao M, Tsutsuura M, Tohse N (2007) Regulation of Cav1.2 current: interaction with intracellular molecules. J Pharmacol Sci 103:347-353.

Kumar A, Foster TC (2002) 17beta-estradiol benzoate decreases the AHP amplitude in CA1 pyramidal neurons. J Neurophysiol 88:621-626.

Kurata K, Takebayashi M, Kagaya A, Morinobu S, Yamawaki S (2001) Effect of beta-estradiol on voltage-gated $\mathrm{Ca}(2+)$ channels in rat hippocampal neurons: a comparison with dehydroepiandrosterone. Eur J Pharmacol 416:203-212.

LaFerla FM (2002) Calcium dyshomeostasis and intracellular signalling in Alzheimer's disease. Nat Rev Neurosci 3:862-872.

Landfield PW (1987) 'Increased calcium-current' hypothesis of brain aging. Neurobiol Aging 8:346-347.

Landfield PW, Pitler TA (1984) Prolonged Ca2+-dependent afterhyperpolarizations in hippocampal neurons of aged rats. Science 226:1089-1092.

Liu F, Day M, Muñiz LC, Bitran D, Arias R, Revilla-Sanchez R, Grauer S, Zhang G, Kelley C, Pulito V, Sung A, Mervis RF, Navarra R, Hirst WD, Reinhart PH, Marquis KL, Moss SJ, Pangalos MN, Brandon NJ (2008) Activation of estrogen receptor-beta regulates hippocampal synaptic plasticity and improves memory. Nat Neurosci 11:334-343.

Luoma JI, Boulware MI, Mermelstein PG (2008) Caveolin proteins and estrogen signaling in the brain. Mol Cell Endocrinol 290:8-13.

Mair W, Dillin A (2008) Aging and survival: the genetics of life span extension by dietary restriction. Annu Rev Biochem 77:727-754.

Markowska AL, Savonenko AV (2002) Effectiveness of estrogen replace- 
ment in restoration of cognitive function after long-term estrogen withdrawal in aging rats. J Neurosci 22:10985-10995.

McEwen BS (1999) Permanence of brain sex differences and structural plasticity of the adult brain. Proc Natl Acad Sci U S A 96:7128-7130.

Meli R, Pacilio M, Raso GM, Esposito E, Coppola A, Nasti A, Di Carlo C, Nappi C, Di Carlo R (2004) Estrogen and raloxifene modulate leptin and its receptor in hypothalamus and adipose tissue from ovariectomized rats. Endocrinology 145:3115-3121.

Mermelstein PG, Becker JB, Surmeier DJ (1996) Estradiol reduces calcium currents in rat neostriatal neurons via a membrane receptor. J Neurosci 16:595-604.

Moosmang S, Haider N, Klugbauer N, Adelsberger H, Langwieser N, Müller J, Stiess M, Marais E, Schulla V, Lacinova L, Goebbels S, Nave KA, Storm DR, Hofmann F, Kleppisch T (2005) Role of hippocampal Ca $1.2 \mathrm{Ca}^{2+}$ channels in NMDA receptor-independent synaptic plasticity and spatial memory. J Neurosci 25:9883-9892.

Morrison JH, Brinton RD, Schmidt PJ, Gore AC (2006) Estrogen, menopause, and the aging brain: how basic neuroscience can inform hormone therapy in women. J Neurosci 26:10332-10348.

Moyer JR Jr, Thompson LT, Black JP, Disterhoft JF (1992) Nimodipine increases excitability of rabbit CA1 pyramidal neurons in an age- and concentration-dependent manner. J Neurophysiol 68:2100-2109.

Murchison D, Griffith WH (2007) Calcium buffering systems and calcium signaling in aged rat basal forebrain neurons. Aging Cell 6:297-305.

Nilsen J, Diaz Brinton R (2003) Mechanism of estrogen-mediated neuroprotection: regulation of mitochondrial calcium and $\mathrm{Bcl}-2$ expression. Proc Natl Acad Sci U S A 100:2842-2847.

Norris CM, Halpain S, Foster TC (1998) Reversal of age-related alterations in synaptic plasticity by blockade of L-type $\mathrm{Ca}^{2+}$ channels. J Neurosci 18:3171-3179.

Norris CM, Blalock EM, Chen KC, Porter NM, Thibault O, Kraner SD, Landfield PW (2008) Hippocampal 'zipper' slice studies reveal a necessary role for calcineurin in the increased activity of L-type $\mathrm{Ca}(2+)$ channels with aging. Neurobiol Aging. Advance online publication. Retrieved May 7, 2008. doi:10.1016/j.neurobiolaging.2008.03.026.

Patel NV, Finch CE (2002) The glucocorticoid paradox of caloric restriction in slowing brain aging. Neurobiol Aging 23:707-717.

Paxinos G, Watson C (1998) The rat brain in sterotaxic coordinates, Ed 4. San Diego: Academic.

Power JM, Wu WW, Sametsky E, Oh MM, Disterhoft JF (2002) Age-related enhancement of the slow outward calcium-activated potassium current in hippocampal CA1 pyramidal neurons in vitro. J Neurosci 22:7234-7243.

Raza M, Deshpande LS, Blair RE, Carter DS, Sombati S, DeLorenzo RJ (2007) Aging is associated with elevated intracellular calcium levels and altered calcium homeostatic mechanisms in hippocampal neurons. Neurosci Lett 418:77-81.

Sarkar SN, Huang RQ, Logan SM, Yi KD, Dillon GH, Simpkins JW (2008) Estrogens directly potentiate neuronal L-type Ca2+ channels. Proc Natl Acad Sci U S A 105:15148-15153.

Scharfman HE, Maclusky NJ (2005) Similarities between actions of estrogen and BDNF in the hippocampus: coincidence or clue? Trends Neurosci 28:79-85.

Scott HC, Sun GY, Zoeller RT (1998) Prenatal ethanol exposure selectively reduces the mRNA encoding alpha-1 thyroid hormone receptor in fetal rat brain. Alcohol Clin Exp Res 22:2111-2117.

Shankar S, Teyler TJ, Robbins N (1998) Aging differentially alters forms of long-term potentiation in rat hippocampal area CA1. J Neurophysiol 79:334-341.

Sherwin BB, Henry JF (2008) Brain aging modulates the neuroprotective effects of estrogen on selective aspects of cognition in women: a critical review. Front Neuroendocrinol 29:88-113.

Simpkins JW, Singh M (2008) More than a decade of estrogen neuroprotection. Alzheimers Dement 4:S131-S136.

Simpkins JW, Anderson WR, Dawson R Jr, Seth A, Brewster M, Estes KS, Bodor N (1988) Chronic weight loss in lean and obese rats with a brainenhanced chemical delivery system for estradiol. Physiol Behav 44:573-580.

Simpkins JW, Wen Y, Perez E, Yang S, Wang X (2005) Role of nonfeminizing estrogens in brain protection from cerebral ischemia: an animal model of Alzheimer's disease neuropathology. Ann NY Acad Sci 1052:233-242.

Sone K, Yamamoto-Sawamura T, Kuwahara S, Nishijima K, Ohno T, Aoyama
H, Tanaka S (2007) Changes of estrous cycles with aging in female F344/n rats. Exp Anim 56:139-148.

Sowers M, Zheng H, Tomey K, Karvonen-Gutierrez C, Jannausch M, Li X, Yosef M, Symons J (2007) Changes in body composition in women over six years at midlife: ovarian and chronological aging. J Clin Endocrinol Metab 92:895-901.

Spencer JL, Waters EM, Romeo RD, Wood GE, Milner TA, McEwen BS (2008) Uncovering the mechanisms of estrogen effects on hippocampal function. Front Neuroendocrinol 29:219-237.

Spruston N (2008) Pyramidal neurons: dendritic structure and synaptic integration. Nat Rev Neurosci 9:206-221.

Suzuki S, Brown CM, Dela Cruz CD, Yang E, Bridwell DA, Wise PM (2007) Timing of estrogen therapy after ovariectomy dictates the efficacy of its neuroprotective and antiinflammatory actions. Proc Natl Acad Sci U S A 104:6013-6018.

Teyler TJ, Vardaris RM, Lewis D, Rawitch AB (1980) Gonadal steroids: effects on excitability of hippocampal pyramidal cells. Science 209:1017-1018.

Thibault O, Landfield PW (1996) Increase in single L-type calcium channels in hippocampal neurons during aging. Science 272:1017-1020.

Thibault O, Porter NM, Chen KC, Blalock EM, Kaminker PG, Clodfelter GV, Brewer LD, Landfield PW (1998) Calcium dysregulation in neuronal aging and Alzheimer's disease: history and new directions. Cell Calcium 24:417-433.

Thibault O, Hadley R, Landfield PW (2001) Elevated postsynaptic $\left[\mathrm{Ca}^{2+}\right]_{\mathrm{i}}$ and L-type calcium channel activity in aged hippocampal neurons: relationship to impaired synaptic plasticity. J Neurosci 21:9744-9756.

Thibault O, Gant JC, Landfield PW (2007) Expansion of the calcium hypothesis of brain aging and Alzheimer's disease: minding the store. Aging Cell 6:307-317.

Toescu EC, Verkhratsky A, Landfield PW (2004) Ca2 + regulation and gene expression in normal brain aging. Trends Neurosci 27:614-620.

Toung TJ, Traystman RJ, Hurn PD (1998) Estrogen-mediated neuroprotection after experimental stroke in male rats. Stroke 29:1666-1670.

Trompet S, Westendorp RG, Kamper AM, de Craen AJ (2008) Use of calcium antagonists and cognitive decline in old age. The Leiden 85-plus study. Neurobiol Aging 29:306-308.

Turturro A, Witt WW, Lewis S, Hass BS, Lipman RD, Hart RW (1999) Growth curves and survival characteristics of the animals used in the Biomarkers of Aging Program. J Gerontol A Biol Sci Med Sci 54:B492-B501.

Ullrich ND, Koschak A, MacLeod KT (2007) Oestrogen directly inhibits the cardiovascular L-type Ca2 + channel Cav1.2. Biochem Biophys Res Commun 361:522-527.

Veng LM, Browning MD (2002) Regionally selective alterations in expression of the alpha(1D) subunit $(\mathrm{Ca}(\mathrm{v}) 1.3)$ of L-type calcium channels in the hippocampus of aged rats. Brain Res Mol Brain Res 107:120-127.

Veng LM, Mesches MH, Browning MD (2003) Age-related working memory impairment is correlated with increases in the L-type calcium channel protein alpha1D (Cav1.3) in area CA1 of the hippocampus and both are ameliorated by chronic nimodipine treatment. Brain Res Mol Brain Res 110:193-202.

Wade GN (1986) Sex steroids and energy balance: sites and mechanisms of action. Ann N Y Acad Sci 474:389-399.

Warren SG, Humphreys AG, Juraska JM, Greenough WT (1995) LTP varies across the estrous cycle: enhanced synaptic plasticity in proestrus rats. Brain Res 703:26-30.

Wise PM, Dubal DB, Rau SW, Brown CM, Suzuki S (2005) Are estrogens protective or risk factors in brain injury and neurodegeneration? Reevaluation after the women's health initiative. Endocr Rev 26:308-312.

Witte AV, Fobker M, Gellner R, Knecht S, Flöel A (2009) Caloric restriction improves memory in elderly humans. Proc Natl Acad Sci U S A 106:1255-1260.

Wong M, Moss RL (1992) Long-term and short-term electrophysiological effects of estrogen on the synaptic properties of hippocampal CA1 neurons. J Neurosci 12:3217-3225.

Woolley CS (1998) Estrogen-mediated structural and functional synaptic plasticity in the female rat hippocampus. Horm Behav 34:140-148.

Woolley CS, McEwen BS (1992) Estradiol mediates fluctuation in hippocampal synapse density during the estrous cycle in the adult rat. J Neurosci 12:2549-2554. 
Woolley CS, Gould E, Frankfurt M, McEwen BS (1990) Naturally occurring fluctuation in dendritic spine density on adult hippocampal pyramidal neurons. J Neurosci 10:4035-4039.

Wu TW, Wang JM, Chen S, Brinton RD (2005) 17beta-estradiol induced $\mathrm{Ca}(2+)$ influx via L-type calcium channels activates the SRC/ERK/cyclicAMP response element binding protein signal pathway and BCL-2 expression in rat hippocampal neurons: a potential initiation mechanism for estrogen-induced neuroprotection. Neuroscience 135:59-72.

Yang SH, Shi J, Day AL, Simpkins JW (2000) Estradiol exerts neuroprotective effects when administered after ischemic insult. Stroke 31:745-750.

Yang SH, Liu R, Perez EJ, Wen Y, Stevens SM Jr, Valencia T, BrunZinkernagel AM, Prokai L, Will Y, Dykens J, Koulen P, Simpkins JW
(2004) Mitochondrial localization of estrogen receptor beta. Proc Natl Acad Sci U S A 101:4130-4135.

Yun SH, Park KA, Kwon S, Woolley CS, Sullivan PM, Pasternak JF, Trommer BL (2007) Estradiol enhances long term potentiation in hippocampal slices from aged apoE4-TR mice. Hippocampus 17:1153-1157.

Zhao L, Brinton RD (2007) Estrogen receptor alpha and beta differentially regulate intracellular $\mathrm{Ca}(2+)$ dynamics leading to ERK phosphorylation and estrogen neuroprotection in hippocampal neurons. Brain Res 1172:48-59.

Zhao L, Jin C, Mao Z, Gopinathan MB, Rehder K, Brinton RD (2007) Design, synthesis, and estrogenic activity of a novel estrogen receptor modulator-a hybrid structure of 17beta-estradiol and vitamin E in hippocampal neurons. J Med Chem 50:4471-4481. 